\title{
Identification, immunoaffinity purification and partial characterization of a human decidua-associated protein*
}

\author{
R. Halperin $\uparrow \ddagger$, E. Hadas§, G. Fleminger§, Y. Ovadia $†$ and P. F. Kraicer $\ddagger$ \\ +Department of Obstetrics and Gynecology, Sackler School of Medicine, Tel Aviv University, \\ Tel Aviv 69978, Israel; $\ddagger$ Department of Zoology and \$Department of Biotechnology, George S. \\ Wise Faculty of Life Sciences, Tel Aviv University, Tel Aviv 69 978, Israel
}

\begin{abstract}
Summary. A crude extract of pooled early-pregnancy decidual tissue was enriched for soluble decidual proteins by exhaustive affinity absorption with antibodies to human serum proteins immobilized on Eupergit $C$. The partly purified extract was used to prepare monoclonal antibodies. A monoclonal antibody was obtained recognizing an antigen present in extract of decidual tissue and not in extract of proliferative endometrium. The monoclonal antibody was used for immunoaffinity purification of the decidua-associated protein. By SDS-PAGE analysis, under reducing conditions it yielded 2 bands at apparent molecular weights of 55000 and 25000 . Under nonreducing conditions a single protein band at apparent molecular weight of 200000 was observed. The $M_{\mathrm{r}} 200000$ protein was named hDP200 and the $M_{\mathrm{r}} 55000$ protein was named hDP55. It is suggested that hDP55 is a subunit of the hDP200. The hDP200 did not react with polyclonal antibodies specific for PP12 and PP14. PP14 has been shown to be immunologically indistinguishable from PEP and $\alpha_{2}$-PEG. Our data therefore suggest that hDP200 is a novel human decidua-associated protein.
\end{abstract}

Keywords: monoclonal antibody; decidua-associated secretory protein; man

\section{Introduction}

Endometrial decidualization is growth and differentiation of a 'new', progestagen-dependent tissue, the decidua, which gradually replaces the functional layer of the endometrium. Pregnancy is not mandatory for growth and differentiation of decidual tissue. It is produced in each normal cycle in the late luteal phase in response to progesterone. Eventually, at birth or menstruation the decidua is shed.

Because decidualization is growth and differentiation of new tisuse, the appearance of deciduaspecific proteins can be anticipated. Human decidual tissue, obtained at early pregnancy, synthesizes and secretes 7 specific proteins in culture (Kisalus et al., 1987). Several decidua-associated proteins have also been described, e.g. PAPP-A (Bischof et al., 1974), AUP (Sutcliffe et al., 1980), PEP (Joshi, 1983), PP12 (Wahlstrom \& Seppala, 1984; Rutanen et al., 1985), EP14, EP15 (Bell et al.,1985a, b), PP14 (Westwood et al., 1988), $\alpha_{2}$-PEG (Bell et al., 1987) and prolactin (Riddick et al., 1978). Immunological identity between the majority of these proteins has been established (Sutcliffe et al., 1982; Julkunen et al., 1986; Bell \& Bohn, 1986), but it is not clear whether these represent a single or several decidua-associated proteins.

In this study, we describe the identification, immuno-purification by a monoclonal antibody, and initial characterization of a human decidua-associated protein. 


\section{Materials and Methods}

Antisera. Rabbit antisera specific for PP14 (Riittinen et al., 1989) and PP12 (Koistinen et al., 1987) were obtained from Dr M. Seppala.

Decidual tissue extraction. Samples of decidual tissue were acquired from 12 elective pregnancy terminations (6-12 weeks after conception) performed by dilatation and curettage. The decidual tissue was manually cleared of embryonic tissues and large blood clots. After thorough washing in cold phosphate-buffered saline, pH 7.4 (PBS), the samples were blotted, frozen and stored at $-20^{\circ} \mathrm{C}$.

Thawed tissues were homogenized (Omnimixer) in 3 volumes of cold PBS for $5 \mathrm{~min}$ at maximal speed. The homogenate was then centrifuged at $3000 g_{\max }$ for $20 \mathrm{~min}$. The collected supernatants were recentrifuged at $100000 \mathrm{~g}_{\max }$ for $1 \mathrm{~h}$. The supernatants were stored at $-20^{\circ} \mathrm{C}$ until further use. Protein concentrations were measured by the method of Bradford (1976) using the BioRad assay kit (Hercules, CA, USA).

Purification of the crude decidual extract by immunosorption. Eupergit $\mathrm{C}$ beads (Rohm Inc., Darmstadt, W. Germany) were washed 3 times with PBS and then with $1.0 \mathrm{M}$-potassium phosphate buffer, $\mathrm{pH} 7 \cdot 5$. Blood-related proteins were removed from the crude decidual extract with antibodies to human serum proteins. Goat antiserum to whole human serum (GAHuS) was concentrated by precipitation with ammonium sulphate at $40 \%$ saturation. The concentrated GAHuS was dissolved in $1.0 \mathrm{M}$-potassium phosphate buffer, $\mathrm{pH} 7.5,96 \mathrm{mg}$ in $5 \mathrm{ml} ; 2.5 \mathrm{~g}$ washed Eupergit $\mathrm{C}$ beads were added. The test tube containing the mixture was agitated by rotation for $16 \mathrm{~h}$ at $4^{\circ} \mathrm{C}$. Residual oxirane groups were blocked by reacting them with $1.0 \mathrm{M}$-ethanolamine at $\mathrm{pH} 9 \cdot 5$, for $4 \mathrm{~h}$ at $4{ }^{\circ} \mathrm{C}$. The GAHuSEupergit $\mathrm{C}$ complex was washed with $1.0 \mathrm{M}$-ammonium acetate buffer, $\mathrm{pH} 10$, for $30 \mathrm{~min}$ at $4^{\circ} \mathrm{C}$ to elute any nonspecifically adsorbed protein. The beads were then thoroughly washed with PBS until the $\mathrm{pH}$ of the effluent reached $7 \cdot 0$.

An extract of pooled decidual tissue containing about $40 \mathrm{mg}$ protein in $2 \mathrm{ml}$ PBS was gently shaken with $2.5 \mathrm{~g}$ Eupergit C-GAHuS conjugate for $16 \mathrm{~h}$ at $4 . \mathrm{C}$. The beads were then sedimented by centrifugation $\left(5000 g_{\max }\right)$ for 5 min, rinsed once with PBS and the rinse was added to the supernatant. The immunological binding activity of the immobilized GAHuS was then regenerated; the immunobound proteins were eluted from the beads with $20 \mathrm{ml}$ $1.0 \mathrm{M}$-ammonium acetate buffer, $\mathrm{pH} 10$, and several washings of PBS.

The immunoabsorption of the pooled supernatants was repeated 7 times by which time there was no further absorption of protein from the tissue extract. The resulting solution of decidua-associated proteins was concentrated on a PM10 membrane in a Diaflo ultrafiltration cell ( $10 \mathrm{ml}$, Amicon).

Preparation of monoclonal antibodies. CB6F 1 mice were immunized by 2 injections, 10 days apart, of $10 \mu \mathrm{g}$ decidua-associated proteins emulsified in an equal volume of Freund's complete adjuvant. After a further 20 days their spleen cells were fused with NSO myeloma cells (Galfre \& Milstein, 1981) as previously described (Hadas \& Theilen, 1987). A resultant hybridoma line (denoted by us as DEC21) was cloned twice by limiting dilution. Ascites fluid was produced in $\mathrm{CB} 6 \mathrm{~F}$ I mice by intraperitoneal inoculation of hybridoma cells 1 day after priming with $0.5 \mathrm{ml}$ Freund's incomplete adjuvant (Mueller et al., 1986). In all subsequent experiments (except as specifically noted) the monoclonal antibody preparation used $(\mathrm{mA}$ ) was partly purified from the ascites fluid by $50 \%$ ammonium sulphate precipitation.

Prepartion of the immunoaffinity column. After conjugation of $1 \mathrm{~g}$ washed Eupergit $\mathrm{C}$ beads with $\mathrm{mAb}$, the $\mathrm{mAb}$ Eupergit $C$ conjugated beads were packed into a column and washed with 10 volumes of PBS. The column was loaded with $10 \mathrm{ml}$ crude decidual extract, containing about $20 \mathrm{mg}$ total protein $/ \mathrm{ml} \mathrm{PBS}$, and then washed with PBS at a flow rate of $30 \mathrm{ml} / \mathrm{h}$ until the effluent was protein-free. Specifically bound proteins were then eluted from the $\mathrm{mAb}$. Eupergit $\mathrm{C}$ with $1.0 \mathrm{M}$-ammonium acetate buffer, $\mathrm{pH} 10$, and concentrated to $1 \mathrm{ml}$ using a Centriflo CF25 ultrafiltration membrane cone (nominal molecular weight cut-off 25000 ; Amicon), and dialysed against PBS.

Polyacrylamide gel electrophoresis. The electrophoresis was performed in the presence of $0.6 \mathrm{M}$-mercaptoethanol in the samples (the samples were boiled before application onto the gel) and sodium dodecyl sulphate (Laemmli, 1970). Protein bands were stained with Coomassie Brilliant Blue R or silver stain (BioRad).

Western blot analysis. Proteins were transferred from the polyacrylamide gels into nitrocellulose sheets (450 $\mathrm{nm}$ nominal pore size) in $20 \mathrm{~mm}$-Tris $-\mathrm{HCl}$ buffer, $\mathrm{pH} 8 \cdot 8$, containing $150 \mathrm{~mm}$-glycine and $20 \%(\mathrm{v} / \mathrm{v})$ methanol using a TE 22 transfer apparatus (Hoeffer); a current of $1 \mathrm{~A}$ was applied for $1 \mathrm{~h}$. The sheets were then cut into strips corresponding with the lanes of the original gel. The strips were stained in a solution of $1 \mathrm{mg}$ Amido black/ml aqueous $5 \%$ methanol $+7 \cdot 5 \%$ acetic acid. The strips were destained by washing in the solvent.

For immunostaining, the strips were incubated with the appropriate antibody diluted (1:500) with low-fat milk for $1 \mathrm{~h}$ at room temperature and then washed several times with tap water. The strips were then reacted for $1 \mathrm{~h}$ at room temperature with goat anti-mouse IgG conjugated with horseradish peroxidase (BioRad) diluted 1:3000 with low-fat milk, and then washed several times with tap water. Immunoreactive bands were visualized by reaction with chloronaphthol (BioRad) reagent $(0.5 \mathrm{mg}$ 4-chloro-1-naphthol $/ \mathrm{ml}$ PBS containing $0.018 \%$ hydrogen peroxide). The reaction was terminated by washing the strips in tap water.

ELISA. The wells of microtitre ELISA plates were coated with the mixture of proteins being examined. They were exposed for $16 \mathrm{~h}$ to a solution containing $1 \mu \mathrm{g}$ protein/well in $0.1 \mathrm{ml} 0.1 \mathrm{M}$-carbonate buffer, $\mathrm{pH} 9 \cdot 6$, at $4^{\circ} \mathrm{C}$. After 


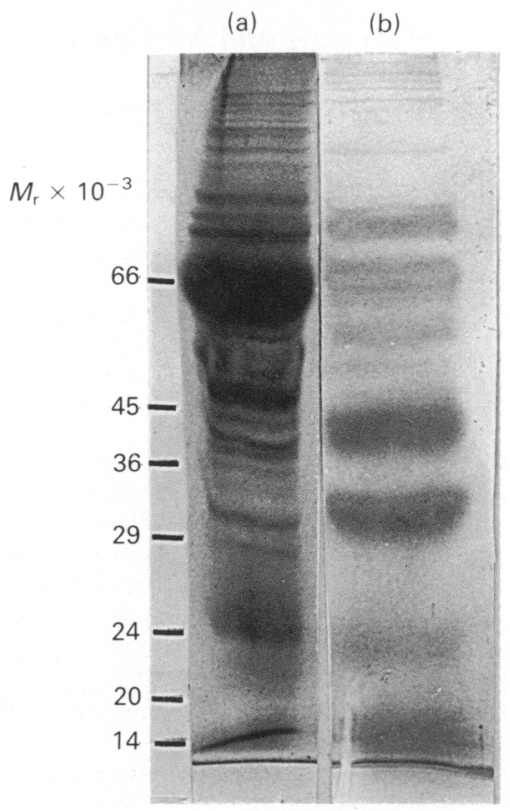

Fig. 1. Analysis of a crude extract of decidua (a) and an absorbed decidua extract (b) by SDSPAGE (10\% gel). Lane A was stained by Coomassie Brilliant Blue R and Lane B by silver stain (BioRad).

washing several times in tap water, $\mathrm{mAb}$ (non-diluted hybridoma culture media or ascites fluids diluted (1:500) with low-fat milk) was added, $0 \cdot 1 \mathrm{ml} /$ well. After $\mathrm{l} \mathrm{h}$ at $37^{\circ} \mathrm{C}$ the wells were washed 5 times in tap water. To each well, $0 \cdot 1 \mathrm{ml}$ goat anti-mouse IgG-horseradish peroxidase complex (BioRad), diluted 1:3000 with low-fat milk, was added and the plates were incubated for $1 \mathrm{~h}$ at $37^{\circ} \mathrm{C}$. After washing several times in tap water, $0.1 \mathrm{ml} o$-phenylenediamine reagent was added to each well and the colour was allowed to develop. The $o$-phenylenediamine reagent contained $2 \mathrm{mg} 1,2-$ phenylenediamine $/ \mathrm{ml}$ in $50 \mathrm{~mm}$-sodium citrate buffer, $\mathrm{pH} 5.0$, containing $0.08 \%$ hydrogen peroxide. The colour was determined by measuring the increase in absorbance at $492 \mathrm{~nm}$ compared to the non-specific absorbance at $405 \mathrm{~nm}$ in an EAR400 Elisa Reader (SLT-Labinstruments, Grödig, Austria).

Staining for the presence of sugar residues. Graded quantities of the decidua-associated protein were applied to a nitrocellulose membrane and stained for the presence of sugar residues by using the hydrazine derivative of horseradish peroxidase (Gershoni et al., 1985).

\section{Results}

\section{Preparation of decidua-specific soluble proteins}

The most obvious sources of contamination of the decidual tissue used in this study were blood and embryonic tissue. At the time of isolation by mechanical separation, an attempt was made to eliminate as much of the fetal tissues as possible. Blood-derived proteins and other antigens crossreacting immunologically with them could be eliminated by repeated batch absorption of the decidual extract with commercial antibodies to whole human serum conjugated to a Eupergit $\mathrm{C}$ carrier. After each absorption, a large decrease in total protein concentration was seen, until, after the 7th absorption, no bands were found in a mercaptoethanol-SDS-PAGE gel stained with Coomassie Brilliant Blue R. Silver staining revealed 7 clearly distinguishable bands (Fig. 1) in SDS-PAGE.

The protein mixture was tested for the presence of albumin by ELISA using a commercial rabbit anti-human albumin antiserum (BioYeda, Rehovot, Israel). None was detected. The absence 


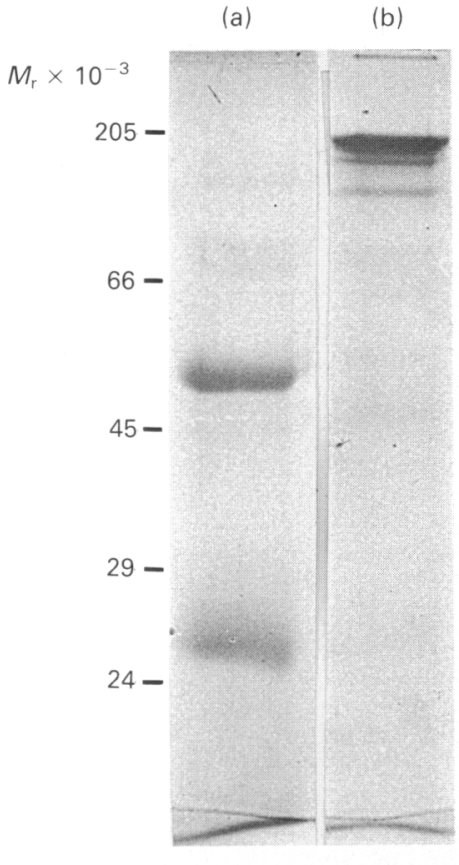

Fig. 2 .

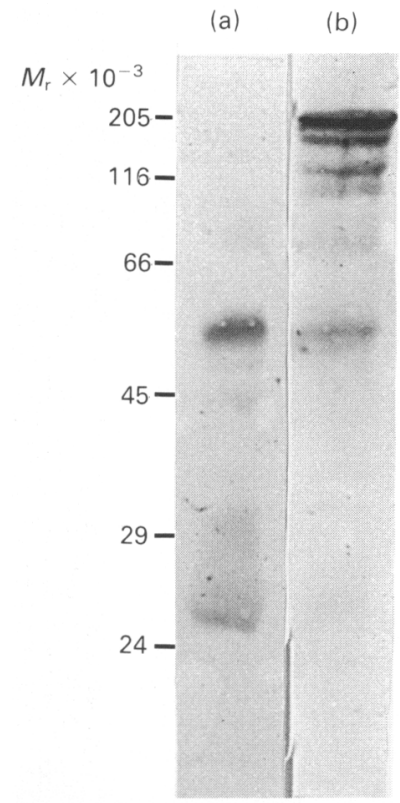

Fig. 3.

Fig. 2. SDS-PAGE analysis of immunoaffinity-purified hDP200. The hDP200 was purified by a single immunoaffinity extraction from the crude extract of decidua by DEC $21 \mathrm{mAb}$ immobilized on Eupergit C (see 'Materials and Methods'). (a) Electrophoresis performed under reducing conditions. (b) Electrophoresis performed under non-reducing conditions.

Fig. 3. Identification of the antigen recognized by the DEC21 mAb by western blot analysis of immunoaffinity purified decidual extract which was separated by SDS-PAGE under reducing (a) and non-reducing (b) conditions.

of albumin provided support for the belief that all of the blood proteins had been successfully eliminated. The remaining 7 proteins were tentatively classed as decidua-specific proteins.

\section{Serological purification and analysis of decidua-specific proteins}

Mice were inoculated with the mixture of putative human decidua-specific proteins, and hybridomas producing decidua-specific antibodies were cloned. The criterion for selection of the hybridomas was that their antibody reacted to a significantly greater extent with decidual extract than with extracts of proliferative endometrium and not at all with serum from males: $9 \mathrm{mAbs}$ were identified which fulfilled these criteria and one, designated DEC21, was selected for further characterization.

This $\mathrm{mAb}$ was partly purified from its ascites fluid by ammonium sulphate fractionation and was coupled to Eupergit $C$ beads. A column of these beads was used to separate the decidua-specific protein. After removal of non-binding proteins, approximately $1 \mathrm{mg}$ immunobound protein(s) was eluted and concentrated. In SDS-PAGE analysis performed under non-reducing conditions, one major protein band was seen with an apparent molecular weight of about 200000 and two minor protein bands at 165000 and 125000 . Under reducing conditions a major and a minor protein band with apparent molecular weights of 55000 and 25000 , respectively, were visible (Fig. 2).

The immunoaffinity purified antigens by mAb DEC21 were also analysed by western blot performed with the same mAb. MAb DEC21 recognized two hDP protein bands with apparent 


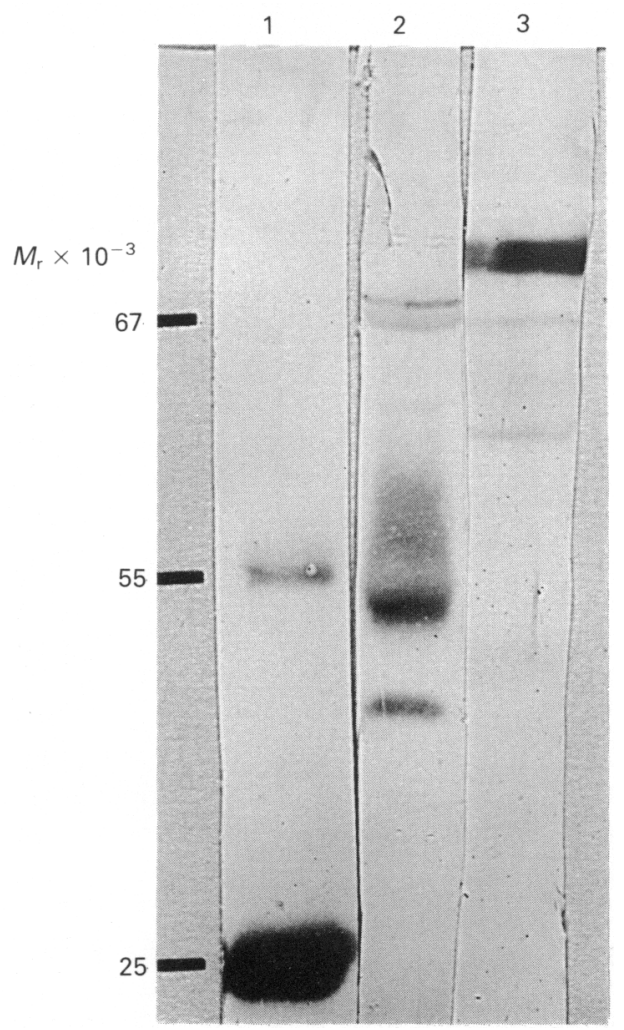

Fig. 4. Comparative immunological analysis of specificity of mAb DEC21 (1), polyclonal antisera specific for PP14 (2) and polyclonal antisera specific for PP12 (3). The antibodies were reacted with western blots prepared from the preparation of decidua-specific soluble proteins.

molecular weights of 55000 and 25000 on reduced gels and a major band of 200000 and several minor protein bands with apparent molecular weights of $165000,125000,100000$ and 55000 on non-reduced gels (Fig. 3). The immunological cross-reactivity of the proteins of $M_{\mathrm{r}} 55000$ and 200000 indicated that the latter is probably a tetramer of the former and the minor protein bands are probably degradation products of the $M_{\mathrm{r}} 200000$ species or dimers and trimers of the 55000 subunit and its degradation product. The 200000 unit was named hDP200 and the 55000 monomer was named hDP55.

Some characteristics of hDP55 are similar to those of PEP, PP14 and $\alpha_{2}$-PEG. Immunological analysis was used to find out whether hDP55 is different from PP14. Western blots were established from the preparation of decidua-specific soluble proteins and were reacted with mAb DEC21 and with antisera specific for PP14 and PP12. As shown in Fig. 4, the hDP55 and the protein of $M_{\mathrm{r}} 25000$ did not react with these antibodies, thus ruling out the possibility of immunological cross-reactivity between hDP200 and PP14 or P12.

Graded quantities of hDP200 were applied to a nitrocellulose membrane and stained for the presence of sugar residues. Positive results were obtained (data not shown), proving that hDP200 is a glycoprotein.

\section{Discussion}

The hDP200 was immunopurified from crude decidual extract by mAb. The hybridoma culture which produced this mAb (designated by us as mAb DEC21) was originally selected on the basis of 
its reaction with the major protein remaining in the decidual tissue extract after removal of nonspecific proteins by immunosorption. Isolation of the protein from purified decidual tissue extract by immunopurification with this same $\mathrm{mAb}$ yielded two bands with apparent molecular weights of 55000 and 25000 in SDS-PAGE analysis performed under reducing conditions. Under nonreducing conditions one major band with an apparent molecular weight of 200000 and two minor bands with apparent molecular weights of 165000 and 125000 were observed. All the bands reacted with $\mathrm{mAb}$ DEC21 in western blot analysis. In the western blot analysis performed under non-reducing conditions two additional minor bands appeared with apparent molecular weights of 100000 and 55000 .

The complex pattern that emerges from our results may be interpreted as follows. The basic unit of the system is probably the protein of $M_{\mathrm{r}} 200000$ that may give rise, under reducing conditions, to the (monomer) protein of $M_{\mathrm{r}} 55000$. The unit of $M_{\mathrm{r}} 25000$ is probably a degradation fragment of the $M_{\mathrm{r}} 55000$ protein, or its subunit, and the proteins of 165000,125000 and 100000 may be degradation products of the hDP200 or partly polymerized forms of the $M_{\mathrm{r}} 55000$ and 25000 proteins. The existence of small quantities of the hDP55 in non-reduced gels probably indicates that the hDP200 is highly susceptible to reduction even under conditions which are generally considred as non-reducing when performing SDS-PAGE analysis. However, additional information is needed to prove the validity of any of these suggestions. The protein was named hDP200 because that of $M_{\mathrm{r}} 200000$ is the major form observed under non-reducing conditions. The monomer, which is the major form observed after reduction of the hDP200, was named hDP55. Several lines of evidence support the hypothesis that hDP200 is a secretory protein. In immunochemical staining, the protein appears to be localized in the glandular and surface epithelium (data not shown). The protein is detected in uterine luminal flushings and it is a glycoprotein (data not shown). We therefore suggest that the hDP200 is a secretory product of the decidual tissue.

As mentioned in the 'Introduction', several secretory glycoproteins of human decidua, immunohistologically localized to the glandular and surface epithelium (Mazurkiewicz et al., 1981; Waites et al., 1988) and exhibiting at least partial serological identity, have already been described. These include PEP, PP14 and $\alpha_{2}$-PEG. The hDP55, being a glycoprotein of $M_{\mathrm{r}} 55000$ secreted from decidual tissue and localized by immunostaining in the glandular and surface epithelium, resembled those proteins. However, hDP55 did not react with antiserum specific for PP14, which has been shown to be immunologically indistinguishable from PEP and $\alpha_{2}$-PEG. Similarly, hDP55 did not react with antibodies specific for PP12. These results suggest, therefore, that the hDP55 is a novel decidua-associated protein.

Three putative major roles for the decidual tissue have been suggested: nutritive support for the developing embryo, defence against aggressive trophoblastic invasiveness and prevention of immune rejection of the embryo. Currently, we can only guess the role of hDP200 in the uterus.

We thank Dr M. Seppala for the gift of antisera specific for PP12 and PP14. This work was performed in partial fulfilment of the requirements for the $\mathrm{Ph} . \mathrm{D}$. degree.

\section{References}

Bell, S.C. \& Bohn, H. (1986) Immunochemical and biochemical relationship between secreted human pregnancy-associated endometrial $\alpha_{1}$ - and $\alpha_{2}$-globulins ( $\alpha_{1}-\mathrm{PEG}$ and $\alpha_{2}$-PEG) and the soluble placental proteins 12 and 14 (PP12 and P14). Placenta 7, 283-294.

Bell, S.C., Hales, M.W., Patel, S., Kirwan, P.H. \& Drife, J.O. (1985a) Protein synthesis and secretion by the human endometrium and decidua during early pregnancy. Br. J. Obstet. Gynaecol. 91, 377-381.

Bell, S.C., Patel, S., Hales, M.W., Kirwan, P.H. \& Drife, J.O. (1985b) Immunochemical detection and characterization of pregnancy-associated endometrial alpha $_{1}$ - and alpha ${ }_{2}$-globulins secreted by human endometrium and decidua. J. Reprod. Fert. 74, 261-270.

Bell, S.C., Keyte, J.W. \& Waites, G.T. (1987) Pregnancyassociated endometrial $\alpha_{2}$-globulin, the major secretory protein of the luteal phase and first trimester pregnancy endometrium, is not glycosylated prolactin but related to $\beta$-lactoglobulins. J. clin. Endocr. Metab. 65, 1067-1071.

Bischof, P., DuBerg, S., Sizoneko, M.T., Schinder, A.M., Begiun, F., Herrmann, W.L. \& Sizonenko, P.C. (1974) 
In vitro production of pregnancy-associated plasma protein A by human decidua and trophoblast. Am.J. Obstet. Gynecol. 148, 13-18.

Bradford, M.M. (1976) A rapid and sensitive method for the quantitation of protein utilizing principle of protein-dye-binding. Analyt. Biochem. 72, 248-254.

Galfre, G. \& Milstein, C. (1981) Preparation of monoclonal antibodies: Strategies and procedures. In Methods in Enzymology, Vol. 73, Immunochemical Techniques, Part B, pp. 3-25. Eds J. J. Langone \& H. Van Vunakis. Academic Press, New York.

Gershoni, J.M., Bayer, E.A. \& Wilchek, M. (1985) Blot analysis of glycoconjugates: Enzyme-hydrazide, a novel reagent for the detection of aldehydes. Analyt. Biochem. 146, 59-63.

Hadas, E. \& Theilen, G. (1987) Production of monoclonal antibodies. The effect of hybridoma concentration on the yield of antibody-producing clones. $J$. Immunol. Methods 96, 3-6.

Joshi, S.G. (1983) A progestagen-associated protein of the human endometrium: basic studies and potential clinical applications. J. Steroid Biochem. 19, 751-757.

Julkunen, M., Raikar, R.S., Joshi, S.G., Bohn, H. \& Seppala, M. (1986) Placental protein 14 and progestagen associated endometrial protein are immunologically indistinguishable. Hum. Reprod. 1, 7-8.

Kisalus, L.L., Nunley, W.C. \& Herr, J.C. (1987) Protein synthesis and secretion in human decidua of early pregnancy. Biol. Reprod. 25, 591-598.

Koistinen, R., Stenman, U-H., Alfthan, H. \& Seppala, M. (1987) Time-resolved immunofluorometric assay of $34-\mathrm{kDa}$ somatomedin-binding protein. Clin. Chem. 33, $1126-[128$.

Laemmli, U.K. (1970) Cleavage of structural proteins during the assembly of the head of bacteriophage T4. Nature, Lond. 227, 680-685.

Mazurkiewicz, J.E., Bank, J.F. \& Joshi, S.G. (1981) Immunocytochemical localization of a progestagenassociated endometrial protein in the human decidua. J. clin. Endocr. Metab. 52, 1006-1008.
Mueller, U.W., Hawes, C.S. \& Jones, W.R. (1986) Monoclonal antibody production by hybridoma growth in Freund's adjuvant primed mice. J. Immunol. Methods 87, 193-196.

Riddick, D.H., Luciano, A.A., Kusmick, W.F. \& Masslar, I.A. (1978) De novo synthesis of prolactin by human decidua. Life Sci. 23, 1913-1921.

Riittinen, L., Stenman, U-H., Alftan, H., Suikkari, A-M., Bohn, H. \& Seppala M. (1989) Time resolved immunofluorometric assay for placental protein 14. Clin. Chim. Acta. In press.

Rutanen, E.M., Koistinen, R., Wahlstrom, T., Bohn, H., Ranta, T. \& Seppala, M. (1985) Synthesis of placenta protein 12 by human decidua. Endocrinology 116, $1304-1309$.

Sutcliffe, R.G., Bolton, A.E., Sharp, F., Nicholson, L.V.B. \& Mackinnon, R. (1980) Purification of human alpha uterine protein. J. Reprod. Fert. 58, 435-442.

Sutcliffe, R.G., Joshi, S.G., Patterson, W.F. \& Bank, J.F. (1982) Serological identity between human alpha uterine protein and human progestagen-dependent endometrial protein. J. Reprod. Fert. 65, 207-209.

Wahlstrom, T. \& Seppala, M. (1984) Placental protein 12 (PP12) is induced in the endometrium by progesterone. Fert. Steril. 41, 781-784.

Waites, G.T., Wood, P.L., Walker, R.A. \& Bell, S.C. (1988) Immunohistological localization of human endometrial secretory protein, pregnancy associated endometrial $\alpha_{2}$-globulin ( $\alpha_{2}-\mathrm{PEG}$ ), during the menstrual cycle. J. Reprod. Fert. 82, 665-672.

Westwood, O.M.R., Chapman, M.G., Totty, N., Philp, R., Bolton, A.E. \& Lazarus, N.R. (1988) N-terminal sequence analysis of human placental protein 14 , purified in high yield from decidual cytosol. $J$. Reprod. Fert. 82, 493-500. 